\title{
The Power of English in Pakistan: Exploring the Views of University Students
}

\author{
Asra Khan ${ }^{1}$, Irshad Hussain ${ }^{2}$, Zohra Khatoon ${ }^{3}$
}

\begin{abstract}
Pakistan is a multilingual country with Urdu as its national language. It is entrenched in one of the post-colonial effects; the influence of the English language and the power which it exerts in Pakistan with regards to the ever advancing global world. The case study aims at voicing the views of university students in a hope that their concerns are addressed at national level, which will ultimately lead to equity in English language classrooms in Pakistan. It seeks to explore the views of Banking and Finance students of Bahauddin Zakariya University, Multan, Pakistan, about the power which English language holds and the multiple ways it is exerted. Forty (40) students, taken through random sampling technique were the participants of study. Quantitative data were collected by administering a questionnaire; whereas, an interview protocol was used for collecting qualitative data. The tools collected data in six categories namely increase in self-confidence, seeking admission in foreign universities, a marker of modernity and social class, attaining a lucrative job, basic schooling and a tag of a good student. The results of the study demonstrated that English language holds a great deal of Power in Pakistan in different walks of life as well as in education of students.
\end{abstract}

Keywords: English in Pakistan, Education, Power of English

\section{Introduction}

Pakistan has a diverse linguistic social and educational scenario with 74 different languages (Simons \& Charles, 2018). It is a multilingual state with many regional languages, their varieties and dialects. According to the consensus 2001 , following is the percentage of speakers of various languages spoken in Pakistan. The national language, Urdu, is the mother tongue of only 7.57 per cent

\footnotetext{
${ }^{1} \mathrm{PhD}$ Scholar, Department of English, Bahauddin Zakariya University, Multan

Email: asrakhan886@hotmail.com

${ }^{2}$ Department of Educational Training, The Islamia University of Bahawalpur Email: irshad_iub@yahoo.com

${ }^{3}$ Assistant Professor, Department of Science and Technical Education, University of Sindh, Jamshoro Email: Zohra.khowja@usindh.edu.pk
} 
of the population though it is very widely used in the urban areas of the country. Pakistan's official language is still English as it was when the British ruled the Country as part of British India (Rehman, 2002). In addition to this, the country has five major indigenous languages given below;

Table 1.1

Pakistani languages and the number of speakers by mother tongue

\begin{tabular}{lc}
\hline $\begin{array}{l}\text { Pakistani } \\
\text { Languages }\end{array}$ & \% of Speakers \\
\hline Punjabi & 44.15 \\
Pashto & 15.42 \\
Sindhi & 14.1 \\
Saraiki & 10.53 \\
Urdu & 7.57 \\
Balochi & 3.57 \\
Other & 4.66 \\
\hline
\end{tabular}

(Source: Pakistan Bureau of Statistics, 2019)

Ironically, with a minor percentage of speakers of English in Pakistan and national literacy rate being low (Shamim, 2008) it still exerts its control and power over the citizens in various domains. Nawaz, Amin and Tatla (2015) maintain that a multitude of International Organisations, for example the United Nations (UN) and its different institutions use English as one of their official language. Similarly, different countries also use English at national level in different ways. Advancements in technology such as the Internet have helped individuals around the world to draw closer, which has aided English to obtain its current status (Barnett et al., 2000; Barnett \& Lee, 2003, p.13).

Petitions in constitution for the implementation of the article 251, commands the state to adopt Urdu as its official language in addition to English. One of the clauses of the article says, "the English language may be used for official purposes until arrangements are made for its replacement by Urdu" (cited in the order of the Supreme court, 2015) gives the national language as increased status, keeping the consideration locked for major number of Pakistanis who are unable to simply understand the Foreign language. By privileging Urdu, Rehman (2006) argues, that it has raised cultural paradoxes whereby the degradation of other indigenous provincial languages has taken place. English-medium schools still remain the first choice of the elite as it provides ladder to the global sociopolitical arenas where the students find they successful and owe it to their skill the foreign language. 
Two major type of schools run simultaneously in Pakistan; the Urdumedium Government-run schools where Urdu is the mainstream language and cater to public education. "Access to English may not be the same for people belonging to different socioeconomic statuses because of different school systems. There are different schools for the elites to which ordinary people have no access" (Haider, 2019.) In all provinces whereby the Government schools use their own provincial language as their major medium of pedagogy. State has created a parallel system of education for the elite run by the armed forces where English is the major medium of instruction including the Cadet colleges, Fauji Foundation (Army) and Bahria Foundation (Navy) and Shaheen Foundation and Air University (Air Force) (Rehman, 2002). Higher education at university level relies on English as medium of instruction in most of the subjects. Hence, students with the least exposure to English who come from Urdu Medium Government schools, find it very hard to cope with these subjects taught in University. The test system itself creates a divide, as Ali and Hamid (2020) argue that these responses encourage 'ritualistic' design practices which negate concerns about test reliability and validity, and which obscure the basis by which winners and losers are created through the education system.

The research focuses on the control and power that English has in Pakistan where Urdu is soon to become at par with this foreign language with respect to its official status. It is based on semi-structured interviews and questionnaires, with frameworks of language and power provided by Tariq Rehman (1996, 2002), Shameem Abbas (1993) and Coleman (2010). On the basis of their concepts of Power of English in Pakistan, and Coleman's concept of English language in development, the research explores the views of University students of Pakistan, $61 \%$ of the population of Multan district uses Saraiki language as their first language. Statistics of the number of Urdu Medium Government schools in Multan District is given below:

Table 1.2

Statistics for District Multan, School Education Department, Government of Punjab

\begin{tabular}{lcccc}
\hline & Level wise School & \multicolumn{2}{c}{ Enrollment } \\
\hline Level & Male & Female & Male Students & Female \\
& Schools & Schools & & Students \\
H.Sec. & 16 & 10 & 22733 & 11151 \\
High & 105 & 55 & 67075 & 44546 \\
Middle & 101 & 119 & 34592 & 34268 \\
Primary & 390 & 622 & 64977 & 60531 \\
Mosques & 19 & 2 & 1300 & 733 \\
Total & 631 & 808 & 190677 & 151229 \\
\hline
\end{tabular}




\subsection{Objectives of the Study}

This study seeks to investigate how English exerts power over the University students of Multan, whose vast majority comes from Urdu medium schools in various adjoining areas of Multan, and who are close to stepping into the practical world and seeking jobs.

\subsection{Research Questions}

This research investigates the following:

1. How English as a foreign language in Pakistan exerts its power in various fields of life?

2. How does English language enable the university students to set their targets for further developments in education?

\section{Literature Review}

Jalal (2004), a former education minister, argues:

"When we subscribe to the experts' view that the economic future of Pakistan is linked with the expansion of information technology, it means that we are recognizing the need for making the comprehension and use of English as widespread as possible. This is now an urgent public requirement, and the government takes it as its duty to fulfill this requirement" (Cited in Paper 14, English as the language for development in Pakistan: Issues, challenges and possible solutions by Fauzia Shamim).

Haider (2019) believes that English language instruction prepares students for variant social roles in different schools focusing on developing different linguistic resources and social capital, which perpetuate class structure. Class or Modernity, as already mentioned, is one domain where English exerts power. In addition to this, it is also a marker of the socio-economic class in Pakistan (Rehman, 2002). It has a high snob value and one can earn a better position in the attainment of employment if is proficient in the English language. Nevertheless, Urdu also provides empowerment to middle class urban societies but gives job access only at a national level. In order to survive in the global market, one cannot deny the use of skills in the foreign language. If one cannot read or write English and can only communicate through Urdu, one can acquire only low grade jobs in Pakistan (ibid). However, in Education, Urdu medium schools do not hold a prestige level which is tagged with the English medium schools of varying quality. University and post-graduate programs offer courses mainly in English. Trade and commerce requires fluency in both or works well in a bilingual context. The recent China Pakistan Economic Corridor (CPEC), a 
collaborated development program in Pakistan, is one example where Chinese and Pakistanis communicate in English or have interpreters where necessary. The majority of people in Pakistan also subscribe to the view that English is the tool for individual and national economic prosperity apart from identity construction (Phan, 2008) and having self-confidence. Pakistani students who seek admissions in the institutions abroad, especially UK and the US, have to go through tests which are mainly based on their English language proficiency. Therefore, English can be said to have a direct relationship with almost every aspect of the professional or mundane domains of life.

Coleman (2010) has tried to ease out the relationship of English with various domains using examples from language and development conferences held in different parts of Asia and Africa since 1993. He concludes that English plays many roles in development, including:

- increasing individuals' employability

- enabling international collaboration and co-operation

- providing access to research and information

- facilitating the international mobility of students, tourists, workers and others

- facilitating disaster relief and disaster preparedness

- Acting as an impartial language in contexts of disharmony (Coleman, 2010, p.15)

The Nobel Prize and Charleston-EFG John Maynard Keynes Prize winner in Economics Amartya Sen (2015) shares this perspective, arguing that 'development as means to expanding the freedoms enjoyed by the members of the society. But freedoms depend also on other determinants, such as social and economic arrangements (for example, facilities for education and health care) as well as political and civil rights (for example, the liberty to participate in public discussion and scrutiny). Furthermore, Rasool and Mansoor (2009) declare English as the language of power in comparison with Urdu, the national language, and other regional languages of Pakistan.

In Pakistan, English is viewed mainly as the language for development at both the individual and national levels. Indeed, the race for individual prosperity and economic development at the national level seem to have overtaken issues of class, identity and fear of cultural invasion from an erstwhile colonial language (Shamim, 2011, p.4). English is the passport to success and upward social mobility' and 'English is the key to national progress' are some common clichés that are interspersed in the formal discourse of official planning and policy 
meetings; more importantly, these clichés reflect the perception of many people both rich and poor - in discussing future life chances (ibid).

Languages, specifically in Pakistan; are being used for economic progress of the country, as a medium of communication internationally or for getting access to latest science and technology, or may be national or intranational communication can be achieved by means of any appropriate language or for local and in-group interaction and communication. These domains should keep under consideration while designing any language policy. However, the national economic progress is more critical in this regard but advancement in any domain highly need English language proficiency; as English is capable of fulfilling most of the above listed demands so English should be taught from very beginning from schools to universities (Mahboob, 2003; p, 23).

As Urdu being national language of Pakistan, serves the purpose of national and intra-national communication so based on the findings of Mahboob (2003) in The Future of English in Pakistan, Urdu should be taught as a compulsory subject but should not be given the status of only medium of instruction $(\mathrm{p}, 23)$ while other regional languages are the medium of communication at local level so they should be offer as optional subject as they are playing vital role in promoting self-image as they are regarding as identity makers in some in-groups interaction.

English should be the medium of instruction, for all the colleges in science and technology and for all the universities in Pakistan, it is endorsed by the White Paper on Education in Pakistan and similarly Education should be used as instructional medium for the teachings of mathematics and sciences in middle and secondary schools (Aly, 2007, p.54). Medium of instruction is something allowing access to political and economic arenas of the country by deciding to whom give more favor and which strata is going to be overshadow through redistribution of power and reshaping of society (Tollefson \& Tsui. 2004, p.2).

After the partition of 1947, English go through some hard times as it was being considered as a representative of British mentality so few Pakistani leaders took significant steps to maintain position of English but soon it became the bone of contention for religious leaders because in their opinion it was new and polished form of colonization (Mahboob, 2003). Indian and Pakistani English have many similarities but at the same time they have some unique features, Pakistani English is considered to be amalgamation of first language of its speakers, social and geographical background and exposure of speakers.

During colonization, British masters introduced English language and education system (Durrani, 2012; Evans, 2002), the implementation of English education system had no place for uneducated people but people having local 
educations also became victim of that system, they developed English education system to produce elite class bureaucrats and vernacular system is for the clerical staff to assist civil servants (Rahman, 2004). Hossain and Tollefson (2007) argues that the educational systems that divide society on linguistics basics are commonly found across the globe, mostly access to English education system create a borderline of social instability between different strata of that particular society (Meganathan, 2011), giving birth to frustration and anxiety among lower class of being deprived from education. In order to cater lower class Pakistani Government introduced "multilingual" education system by supporting local languages, national language and English language equally (Canagarajah \& Ashraf, 2013). Coleman (2010) supports this multilingual system as it is more effective to use mother tongue at early stages. Waseem and Asadullah (2013) hold a view point that multilingual education system of Pakistan is mainly due to difference in mode of instruction as English- Urdu medium divide is further intensified by Higher Education Institutions (HEI) so English becomes modes of instructions in elite class institutions with high fee structure making it more attractive for less privileged class and creating hurdles for students to enter into that privileged institutions.

Mendez and Garcia (2011) have explored the elementary students' power and solidarity relations in an EFL classroom. They are of the view that there are various forms of exercising power and solidarity in the classroom and that power can be resisted and changed whereas solidarity helps protect friends. Their research however is confined to EFL classroom. Students in Pakistan have both positive and negative attitudes towards the usage of the English language, say Jabeen, Mahmood and Rasheed (2011) and believe that English language in Pakistan has progressed beyond the EFL status. The learning process of English itself, in a non-learning environment is not easy (Tian \& Dumlao, 2020).

"Power relations are exerted by what is considered to be a 'good student' to fulfill the school duties" (Cornelious \& Herrenkohl, 2004, p. 468). They assert that a good student, can exert power over others, and a general perception of a good student in Pakistan in not only the one with higher grades but also the one who can speak good English. However, Rauf and Iqbal (2008) have explored how English as a foreign language complicates the process of learning for Pakistani immigrants in American institutions. They believe it is language that has the power to make one confident and successful. Khalid (2016) in her article highlights that there is an increase desire among Pakistani students to learn English so as to enter into the world of international market while keeping the national language secure. In the same context, Hussain and Zaman (2011) explore that girls show lesser anxiety and a more positive attitude than boys 
towards the learning of a foreign language. There is however, enough room to analyze perceptions of university students in Pakistan and their views about the power and control that the language exerts on them with reference to various fields of life. Although much work has been done on the importance of the said language, however, the ground reality which the university students face in the classroom and outside, needs to be explored and explained in their words. Hence, this paper seeks to explore the power that English exerts in various fields and the university students' perception about the language and its role in their future endeavors.

\subsection{Research Design}

\section{Research Methodology}

The research under study employs semi-structured interviews and the quantitative analysis through questionnaires. In this study, research is inclined towards quantitative method, utilization of quantitative technique involves one rule and that is to "to collect as much data as possible within time and expense constraint", as larger sample tend to be representative and so more likely to be generalizable (Leary, 2004). According to MacDonald and Headlam (2009), sample collected through quantitative method is to "sorted, classified and measured", intent to answer questions such "how many?" how long? To which degree? Thus in the present situation, quantitative method will be more effective in achieving the goal of generalization of results through selected sample.

\subsection{Population of Study}

Forty (40) MBA students from Banking and Finance Department of Bahauddin Zakariya University, Multan were a part of this research. Multan is a city with many suburban areas around it and a huge number of students secure admission in this university from those areas. The peripheries of Multan are inundated with Govt. Urdu medium schools and a few English medium schools of medium quality. In random sampling "each element in the population has an equal chance of selection", ignoring researcher`s prejudices (Leary, 2004). In this technique, it is highly recommend that every element of the sample willingly participate and easily accessible. It is considered to be most simplified and fair technique of sampling so generalizability is quality of that method. Careful selection of random sampling for this study is due to the fact that participants were more likely to highly differ in their academic, social and geographical backgrounds so through random sampling researcher is aiming to choose a sample which is appropriate representative of the population. 


\subsection{Sample and Sampling Technique}

Randomly selected forty (40) MBA students from Banking and Finance Department of Bahauddin Zakariya University, Multan were a part of this research.

\subsection{Instrumentation}

Semi-structured interviews were conducted in order to understand their views related to the power exerted by English on them, how it controls their present studies, molds the perception of people around them and their future endeavors. Leary (2004) suggested that in collection of primary data for research involving surveys need direct interaction with respondents either through interviews or through any other possible medium; interviews can be structured, unstructured or semi-structured. Structured interviews tend to be planned and more strict while unstructured are the one which allow flexibility by giving more freedom to respondent and facilitating researcher by allowing him/her to made changes where needed. On the other hand, semi-structured interviews are preplanned questions and highly formal techniques of recording but it try to accommodate needs of respondents and researcher by giving relaxation in changing question sequence and filtering appropriate information. Semistructured interviews can be regarded as user and participant friendly as interviewer usually start with a defined question but then move towards conversational mode in order to get more natural answers (p.164).

\subsection{Data Collection}

To further create an authenticity of views, a survey using a questionnaire was carried out as in some latest research studies (Khodadady \& Navari, 2012). Both the methodologies give a true picture of how University students harbor views about English and in what ways are they controlled by it.

\section{Data Analysis and Interpretation}

For the qualitative data analysis, the researcher has taken into account the participants' views of English as a means of exerting power in various ways on the University students. Social practice, Attitude change, views on school-level education, acquiring lucrative jobs, seeking admission in foreign universities and impact on personality were the major themes of exploration of their ideas. English has a very powerful control over the university students as without it they feel they lag behind in almost every aspect of life and proficiency and skill in the use of English bolsters their confidence. A detail of these aspects was further explored by the use of questionnaire and questions reflected each of the above mentioned categories. Discussion is based on the percentages acquired through the questionnaire which clearly indicate their general views about each 
of these categories. Both, interview and questionnaire helped in obtaining the results.

The six categories used to explore the views about Power of English are as follows:

1. Students' responses to increase in self-confidence

2. Seeking admission in foreign universities

3. Marker of Modernity and social class

4. Lucrative job

5. Views about basic schooling

6. Tag of a good student

The discussion of the above mentioned categories mainly focused $\%$ of agree and disagree; as 'neutral' implied that the students do not have a clear and a distinct view about the Power exerted by English in Pakistan. Hence, it was not discussed.

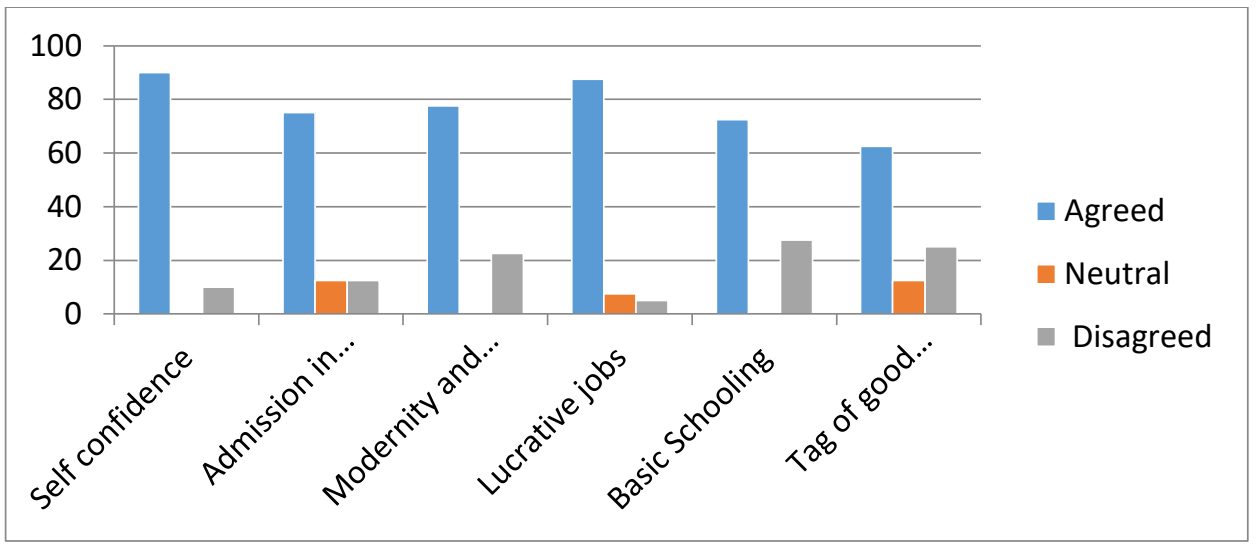

Figure 3: The breakdown of categories where English exerts Power in Pakistani context

\subsection{Students' response to the increase in self-confidence by the use of English}

Results of the first category (My self-confidence has improved with my enhanced exposure to the language at University. The more I'm able to use it, the more confident I feel) displays that 36 out of 40 participants 'agreed.' In total, 90\% respondents view English as a language which enables them to feel more confident thus having a positive impact. 


\section{Excerpt 1}

School never gave me enough confidence. In university, I realized the importance of English as our teachers teach us mostly in English and my classmates tend to mix English with Urdu more now which has begun to enhance my level of confidence. Due to more exposure to English now I can easily use English in my daily discourse with peers and on social media too.

Four (4) students out of $40(10 \%)$ viewed English as a source of shattering the confidence since the Urdu medium schools particularly from where they got their primary and secondary education from, did not prepare them for this language competence and hence, has made them shy or hesitant to even try using it.

\section{Excerpt 2}

Coming from an Urdu medium school, and having an altogether different medium of instruction now, I feel I don't understand when teachers teach me in English, perhaps because I'm not used to it. I lose all my confidence when I see students with good English, coming from English medium schools, speaking so confidently.

\subsection{Viewing English as a passport to admission in Foreign Universities (especially in UK and the US)}

In response to the survey questionnaire statement "Viewing English as a passport to admission in Foreign Universities (especially in UK and the US.) The results in figure 1 show that 30 out of $40(75 \%)$ of the students considered English as a passport to admission in foreign universities.

A participant who is trying to get admission in foreign university mentioned that I have finally realized how important English is to us because without having an adequate proficiency in the language, we cannot cope with international requirements of seeking admission in good international universities. There were only 5 out of 40 students who disagreed and viewed English as not one of the foremost prerequisites in seeking admission rather they considered practicing the past test exams without much fluency and proficiency in the language could get them an entry into the university.

The importance of English language was recognized by major students. However, a small number of students (12.5\%) disagreed which might be due to the fact that the Urdu medium teaching strategies imbibed in them make them view the language use as just another subject, which can be memorized and crammed for getting good grades. 


\subsection{Good English Language or the use of English in speaking and writing especially is a marker of modernity and renders me a member of a high social class}

Results of the survey questionnaire statement shows that 31 out of 40 $(77.5 \%)$ of the students responded positively to the statement while 9 students out of $40(22.5 \%)$ of the students responded to the statement negatively. None of the students seemed confused about the status of English in Pakistan and hence, no neutral answers were received. Mayr (2008) cites Focault (1980) that "power is a productive network which runs through the whole social body which is characterized by a complex and continuously evolving web of social and discursive relations" (131). Anderson et al., (2009) in quoted by Ambreen (2014) to show the significance of social interaction. One response of the participant was as follows:

\section{Excerpt 3}

Students who speak English is their daily discourse or tend to mix it with Urdu more often in class or outside, give an impression that they have a schooling from some elitist English medium school and belong to an upper class in terms of the social strata. They are also considered 'modern' and have a Westernized appeal either by the attire that they don or by the accent they produce while talking in English.

According to the data, $77.5 \%$ of the university students agreed to this notion of modernity and social class. Rehman (2002) points out that language is a marker of socio-economic class in Pakistan. Students who didn't approve of this view, assumed language as their own identity, and if they are Punjabis or Saraiki's they are proud of it and labelled students with good capability of English as 'complexed.' This opinion has a close nexus with the history of Pakistan being a colonized state and such views about English also prevail in Pakistan. Most University students however, consider it as a marker of modernity and social class.

\subsection{It is only through the use of good English that I will be able to get a lucrative job in Pakistan and abroad.}

The result of the survey in the above mentioned statement shows that 35 out of 40 students $(87.5 \%)$ agree with the above statement. 2 students out of 40 disagreed (5\%) while $3(7.5 \%)$ remained neutral. Coleman (2010) in his paper describe the relationship between migrants' language skills and their earning, finding reveals that the use of 'destination language' in their home country is directly linked to their fluency in destination country. Rehman (1996) agrees with the same view that English is the key to power as far as lucrative and 
powerful jobs are concerned. One of excerpts of the interview in which a students agreed with the view presented in the statement above is as follows:

\section{Excerpt 4}

I have seen people at top posts in military, bureaucracy and banking specially, in my own family as well, who are very fluent and good speakers of English. Not only can they communicate well in English, but it has proved a ladder for them to professionally grow and represent their companies internationally. In Pakistan, if you are unable to speak or write English, you are outcast from a number of jobs, at least profitable ones. For them either a business can be a good idea if they have enough money, or a job with a much less prestige.

The excerpt shows clearly that the students in a vast majority consider English to be powerful enough to get them good, lucrative jobs. The participant also mentioned that students amongst us, who give presentations in good English, are encouraged by the teachers and such seniors of ours are at good posts in jobs. Students, who did not agree with this view, opined that only good marks take you to the top in jobs. One just needs to be literate enough and should have good qualification. English was not their focus for getting good jobs.

\subsection{People should prefer sending their children, if they have resources, to English medium schools as a good basis of the English language helps them in their higher studies}

Results of the survey questionnaire of the above statement reveals that 29 out of $40(72.5 \%)$ students agreed that if resources allow, one must try to send their children to English medium schools. One of the participants' views from the interview is as follows:

\section{Excerpt 5}

One should, at every cost, send their children to English medium schools in order to get more exposure to the language. I see students demotivated and discouraged because they find it something strange to write or speak in. They are not used to it and have never been motivated to do so apart from the necessary in school. If resources allow, one must make this effort. Now being in University, I've realized the importance of English since the primary level. All our subjects are taught and tested in English.

Teaching methods in English-medium institutions are more humane, modern, innovative and interesting than in the Urdu-medium schools says Rehman (2005). The results indicate that students view English medium schools as providers of basis of the language at least better than the Urdu-medium schools which give no exposure to the English language which it difficult for them to survive successfully in the higher educational systems. Students who did 
not agree (11 students, 27.5\%) with the statement were of the view that our parents have got a good job without being able to go to an English medium school and also that not all English medium schools give an exposure better than the Urdu-medium ones. All students had clear views regarding this statement and none was responded in neutral.

\subsection{Students with good English skills are generally considered as 'good students' and have higher levels of motivation irrespective of their past grades}

Students were also asked to explore their views about students who have a good proficiency in English and are tagged as 'good students' irrespective of their past grades. Not only this, but they also opined about their motivational levels. The results show that 25 out of 40 students $(62.5 \%)$ hold views that yes such students are generally considered or are taught with pre-conceived notion that are good students. One participant's views are as follows:

\section{Excerpt 6}

Students who have good English language skills are generally considered good by the teachers and this encourages them and motivates them to study hard and perform well. It is the attitude of the teachers, family members and the society that such an impression prevails.

On the contrary, 10 students out of 40 (25\%) disagreed and held views that students with good English skills are not always considered good. The interview discussion reveals that such students believed that marks speak for themselves and even if you cannot communicate well in English, you are still considered a good student. 5 out of 40 students did not a have a clear view about the statement. "Power relations are exerted by what is considered to be a 'good student' to fulfill the school duties" (Cornelious \& Herrenkhol, 2004).

\section{Discussion}

According to the results of the study, majority of the students responded positively to all the six categories which were explored through this research. The power of English language takes various forms; it is evident through selfconfidence, admissions in a renowned International university, is a marker of modernity, helps achieve a lucrative job and gives a tag of a 'good' student. Rehman (1996) mentions that the English language is considered to be the language of Power in local culture. It empowers them with self-confidence and brings them at par with the international scope of academics (ibid). However, there are not enough teaching techniques and facilities in order to equip teachers who teach English through the GTM (Grammar Translation Method) and the exams are based on a test of memory. Richards and Rogers (2000) argue that the new era has questioned and rejected the Grammar-Translation Method as the 
demand of oral proficiency in foreign languages has increased. This is a method only employed where there is little need for a speaking knowledge of the language. Hence, the ability to employ English in everyday discourse does become a hassle for the students; however, once they gain the knack of using it, it gives them a feel of a bolstered confidence. Hajar (2018) argues that students have to go through a lot of hard to increase their scores of IELTS and TOEFL in order to score admission in good universities abroad and ultimately achieve their vision. Haider (2019) finds through his study that English language instruction prepares students for variant social roles in different schools focusing on developing different linguistic resources and social capital, which perpetuate class structure. Hence, where English imposes its power as a marker of modernity, the elite schools, as the participants responded, make a social divide in the society. He further states that the knowledge of English is a key indicator of social class and people consider it superior to other languages (Shamim, 2008). English is used as a control mechanism to play a gate-keeping role in access to higher education and key social positions (Coleman, 2010; Rahman, 2002). Hence, the perceived prestige associated with the language and its controlling mechanisms lead to the factors under inquiry while enhancing the issues of English language learning for low socio-economic status (SES) students, who already struggle with a different mode of instruction at university level from that of public schools in Pakistan.

\section{Conclusion}

With the dominance of the Colonial powers and the ever increasing technological advancements taking place, since the last century, English language has not only become more powerful and an icon of modernity, prosperity and key to a high social class, but also a privilege in acquiring modern education and lucrative jobs. University students in Pakistan have clear views regarding the power English exerts; it has become a cornerstone of success in society, education or any other field of life, and without the sufficient skills, it is impossible to come at par with the ever advancing global world. They see bright prospects in having good English language skills. Keeping in view the Pakistani context, students from the Government-run schools where the medium of instruction is Urdu, have more problems communicating, written or verbal, as compared to the English medium private schools (especially the elite). This case study did not seek to explore the factors due to which most of the students having a background of Urdu medium schools, lag behind in coping with the international requirements of entering into the good universities of the world, especially in UK and the US, which require an adequate amount of the language 
skills. Hence, the findings of the article, can be applied to future researches aiming to explore the above mentioned area.

\section{Recommendations}

The study recommends an inquiry into the teaching methodologies employed in schools all over Pakistan which calls for an equity in the instructional techniques, medium of instruction, curriculum and assessment in order to bridge gaps among a variety of schools. Minimization of this gap can pave way towards narrowing academic differentiation in English language learners in university classrooms which can be a huge challenge for the language teachers. English Language Teaching (ELT) must focus on pedagogy as well as on wider issues such as language policies and practices (Shamim \& Rashid, 2019).

\section{References}

Aly, J. (2007). Education in Pakistan: A White Paper. Islamabad: Pakistan Ministry of Education.

Ambreen, T. (2015). The Influence of English Second Language Learning On Pakistani University Students' Identity. Journal of Procedia- Social and Behavioral Sciences, 19(2), 379-387

Anderson, N. (1999).Exploring second language reading: Issues and strategies. Boston, MA: Heinle \& Heinle.

Asadullah, S. W. (2013). Linguistic domination and critical language. ProcediaSocial and Behavioral Sciences, 799-820

Barnett, G. \& Lee, M. (2003) Issues in Intercultural Communication Research. In Pakistan'. Journal of Research (Faculty of Languages \& Islamic Studies), 6, 27-33.

Barnett, M. (2000). Syntactic and lexical/ semantic skills in foreign language reading: Importance and interaction. The Modern Language Journal, 70, 343-349.

Coleman, H. (2010). Teaching and Learning in Pakistan: The Role of Language in Education. Islamabad: British Council.

Cornelius, L., \& Herrenkohl, L. R. (2004). Power in the Classroom: How the Classroom Environment Shapes Students' Relationships with Each Other 
and with Concepts. Journal of Cognition and Instruction, 22(4), 468471.

Foucault, M. (1980). Power/knowledge: Selected interviews and other writings 1972-1977. New York: Pantheon Books.

Méndez García, M., \& Pérez Cañado, M. (2011). Multicultural Teamwork as a Source of Experiential Learning and Intercultural Development. Journal of English Studies, 9, 143. doi: 10.18172/jes.169

Government of Pakistan. (n.d.). School Education Department. Retrieved from http://schoolportal.punjab.gov.pk/schoolInfoNew.asp?distId=361-Multan.

Haidar, S. (2019) Access to English in Pakistan: inculcating prestige and leadership through instruction in elite schools. International Journal of Bilingual Education and Bilingualism, 22(7), 833-848, doi: 10.1080/13670050.2017.1320352

Hajar, A. (2018) Motivated by visions: a tale of a rural learner of English. The Language Learning Journal, 46(4), 415-429, doi: 10.1080/09571736.2016.1146914

Headlam, S. M. (2009). Research Methods Handbook. Manchester: Centre for Local Economic Strategies.

Hussain, M. A., Shahid, S., \& Zaman, S.A. (2011). Anxiety and Attitude of Secondary School Students towards Foreign Language Learning. Procedia Social and Behavioural Sciences. 29, 583-590.

Jabeen, F., Mahmood, A. M., \& Rasheed, S. (2011). An Attitudinal Study of Pakistani English. Interdisciplinary Journal of Contemporary Research in Business, 3(5), 109-119.

Jalal, Z. (2004). Language policy in Pakistan. In S. Mansoor (Ed.), Language policy, planning, \& practice: A South Asian perspective (pp. 23-26). Karachi, Pakistan: Agha Khan University. 
Khalid, A. (2016). A Study of the Attitudes and Motivational Orientations of Pakistani Learners toward the Learning of English as a Second Language. Sage Journal. Retrieved from https://journals.sagepub.com/doi/10.1177/2158244016665887

Khodadady, E., \& Navari, S. (2012). Foreign Language Identity and its Relationship with Travelling and Educational level. English Language Teaching, 5(3), 30-39.

Leary, Z. (2004). The essential guide to doing Research. London: SAGE publications.

Mahboob, A. (2003). The English Language in Pakistan: A brief overview of its history and linguistics. Pakistan Journal of Language. 4(1).

Mahboob, A. (2020). The Future of English in Pakistan. Retrieved, from https://www.academia.edu/816225/The_Future_of_English_in_Pakistan

Mansoor, S. (2005). Language Planning in Higher Education: A Case Study of Pakistan. Journal of Language Identity \& Education, 11(5), 355-358.

Ali, M., \& Hamid, O. (2020) Teaching English to the Test: Why Does Negative Washback Exist within Secondary Education in Bangladesh? Language Assessment Quarterly, 17(2), 129-146.

Narayanan, R., et al. (2008). Some Factors Affecting English Learning at Tertiary Level. Iranian Journal of Language Studies, 2, 485-512.

Nawaz, H., Amin, M., \& Tatla, I. A. (2015). Factors Affecting Students' Motivation Level to Learn English as a Second Language in the Pakistani University Context. Journal of Research and Reflections in Education, 9(2), 103-115. Retrieved from: http://www.ue.edu.pk/jrre

Pakistan bureau of Statistics (2019). Retrieved from http://www.pbs.gov.pk/content/population-mother-tongue

Rahman, T. (1996). Language and Politics in Pakistan. Karachi: Oxford University Press. 
Rahman, T. (2002). Language, Ideology and Power: Language-Learning among the Muslims of Pakistan and North India. Karachi, Pakistan: Oxford University Press.

Rahman, T. (2006). Passports to privilege: The English-medium schools in Pakistan. Peace and Democracy in South Asia, 1(1).

Rashid, F. S. (n.d.). The English/Urdu-Medium Divide in Pakistan: Consequences. Journal of Education and Educational Development.

Rassool, N. and Mansoor, S. (2009). Contemporary issues in language, education and development in Pakistan. In N. Rasool (Ed.), Global Issues in Language, Education and Development: Perspectives from Post-colonial Countries, 218-244. New Delhi: Orient Longman.

Rauf, S., \& Iqbal, H. (2008). Power of Linguistic Privilege: Critical Discourse Analysis of the Narratives of Pakistani Immigrant Students in American Schools. Bulletin of Education and Research December 2008, 30(2), 4560 .

Sen, A. (2015). Bringing Ethics into the Capitalist Model: Amartya Sen's Approach to Economic Theory and Financial Capitalism. Lisa e-journal. Retrieved from: https://lisa.revues.org/8233

Shamim, F. (2011). English as the language for development in Pakistan: Issues, challenges, and possible solutions. In H. Coleman (Ed.), Dreams and realities: Developing countries and the English language. London, England: The British Council. Retrieved from http://teachingenglish.britishcouncil.org.cn/sites/teacheng/files/Z413\%20 EDB\%20Section14.pdf

Shamim, F., \& Rashid, U. (2019). The English/Urdu-medium divide in Pakistan: Consequences for learner identity and future life chances. Journal of Education and Educational Development, 6(1), 43-61

Shamim, F., \& Allen, P. (2000). Activity types and patterns of interaction in language classrooms in Pakistan. Karachi: Institute for Educational Development, Agha Khan University. 
Simons, G. F. \& Charles D. (2018). Ethnologue: Languages of the world. Retrieved from http://www.ethnologue.com

Tian, W., \& Dumlao, R. P. (2020). Impacts of Positioning, Power, and Resistance on EFL Learners' Identity Construction through Classroom Interaction: A Perspective from Critical Classroom Discourse Analysis. The Qualitative Report, 25(6), 1436-1460. Retrieved from https://nsuworks.nova.edu/tqr/vol25/iss6/2

Tsui, J. T. (2004). Medium of instruction policies: which agenda? Whose agenda? London: Lawrence Erlbaum Associates.

\section{Citation of this Article:}

Khan, A., Hussain, I., \& Khatoon, Z. (2020).The Power of English in Pakistan: Exploring the Views of University Students. International Journal of Innovation in Teaching and Learning (IJITL), 6(1), 84-103. 